\title{
Türkiye'de Okul Öncesi Dönemde Matematik Alanında Yapılan Çalışmalara İlişkin Bir İçerik Analizi
}

DOI: $10.26466 /$ opus.778998

\author{
$\underline{\text { Rukiyye Yıldız Altan }}$-Hilal Genç Çopur** - H. Elif Dağlığlu*** \\ * Arş. Gör., Gazi Üniversitesi Gazi Eğitim Fakültesi, Ankara/Türkiye \\ E-Posta: yildizrukiyye@gmail.com \\ ORCID: $\quad$ 0000-0002-9233-9444 \\ * Arş. Gör., Kırşehir Ahi Evran Üniversitesi, Eğitim Faültesi, Kırşehir/Türkiye \\ E-Posta: hilal.genc40@gmail.com \\ ORCID: $\quad \underline{0000-0002-3030-2080}$ \\ * Prof. Dr., Gazi Üniversitesi Gazi Eğitim Fakültesi, Ankara/Türkiye \\ E-Posta: edaglioglu1@gmail.com \\ ORCID: $\underline{0000-0002-7420-815 X}$
}

$\ddot{O} z$

Bu araştırmada, Türkiye'de okul öncesi dönemde matematik eğitimi ile ilgili son yedi yılda yapılan lisansüstü tezler ve bilimsel makalelerin incelenmesi amaçlanmıştır. Araştırma betimsel nitelikte olup, nitel araştırma deseninde kurgulanmıştır. Araştırmada nitel araştırma metodolojisi kullanılarak amaçl örneklem yönteminden yararlanılmıştır. Veri toplamak için doküman inceleme tekniğinden yararlanılmış ve veri toplama aracı olarak araştırmactlar tarafindan oluşturulan "Araştırma İnceleme Formu" kullanılmıştır. Araştırmada elde edilen veriler tümevarım içerik analizi yaklaşımı ile çözümlenmiştir. Bulgular, okul öncesi dönemde matematik eğitimi ile ilgili yapılan araştırmaların büyük çoğunluğunun makalelerden oluştuğunu göstermektedir. Bu çalışmalarda özellikle nicel araştırma yöntemlerinin kullanıldığı, araştırmaların çoğunun örneklem grubunu çocukların oluşturduğu, veri toplama aracı olarak sıklıkla anket ve çocukların matematik gelişimini belirlemeye yönelik ölçeklerin kullanıldığı belirlenmiştir. Bu bağlamda okul öncesi dönemde matematik eğitimine iliş̧kin çocuğun ailesi, öğretmenleri, eğitim ortamı gibi unsurları birlikte veya ayrı ayrı ele alındı $\breve{g} ı$, farklı araştırma yöntemlerinin kullamıldı̆̆ çalışmaların planlanması önerilmektedir.

Anahtar Kelimeler: 0-6 yaş, matematik eğitimi, bilimsel makale, lisansüstü tez. 


\title{
A Content Analysis on Studies Conducted on Math Education in Preschool in Turkey
}

\begin{abstract}
The aim of this study was to examine graduate dissertations and scientific articles on mathematics education in preschool period conducted between 2012 and 2019 in Turkey. It was a descriptive as well as qualitative research. Based on qualitative research methodology, the study adopted purposive sampling. Document review was used for data collection and "Research Review Form" which was developed by researchers was used as data collection tool. The data were analysed by inductive content analysis approach. The findings showed that the majority of studies that examined mathematics education in preschool period were research articles. According to findings, mostly quantitative research methods were used, samples consisted of children, and data collection tools were questionnaires and scales that determine the mathematical development of children. Accordingly, future research studies on mathematics education in preschool period can be designed by taking into account elements like parents, teachers and the educational setting together or separately, and combining different research methods.
\end{abstract}

Keywords: 0-6 years of age, math education, scientific articles, thesis. 


\section{Giriş}

Okul öncesi dönem, doğumdan ilkokulun başlangıcına kadar süren, çocukluk yıllarını kapsayan, onların gelişimlerine uygun öğrenme ortamları sağlayan ve tüm gelişim alanlarını destekleyen bir eğitim sürecidir. Bu dönemde, çocuklar için hızlı bir gelişim süreci söz konusudur. Bununla birlikte literatürde erken matematik eğitiminin, kısa ve uzun vadede çocukların gelişimine olan katkısı konusunda fikir birliği olduğu görülmektedir (Björklund, Magnusson ve Palmér, 2018; Newton ve Alexander, 2013). Okul öncesi dönem çocukları üzerinde yapılan bazı deneysel çalışmalar, matematik kavram ve becerilerinin kazanılmasına ilişkin matematik çalışmalarının ilkokula başladıklarında çocukların matematik yeterliliklerinde farklılıklar yarattığını ve bu farklılıkların okul hayatı boyunca hatta daha sonrasında da devam ettiğini göstermiştir (Magnuson, Duncan, Lee ve Metzger, 2016; National Research Council, 2009; Nguyen vd., 2016). Bu bağlamda matematik okuryazarlı̆ğ ve becerilerinin, sadece çocukların okul başarısı için değil aynı zamanda yetişkinlikteki mesleki kariyerleri açısından da önemli olduğu görülmektedir (Claesens ve Engel, 2013; Dağlığlu, Dağlı ve Kılıç, 2013; Lundetræ, Gabrielsen ve Mykletun, 2010). Bu durum okul öncesi dönemde çocuklara verilen matematik eğitiminin, onların ileriki yıllarda başarılı bir matematiksel düşünme yeteneği kazanmalarında ve ilkokula hazır olmalarında önemli olduğunu; uzun vadede düşünüldüğünde matematiği anlamanın çocukların iş ve kariyerine yön verebilecek düzeyde etkili olduğunu ortaya çlkarmaktadır.

Son yıllarda fen bilimleri ve matematik alanlarında yaşanan gelişmeler, ülkelerin bu alanlara yönelik eğilimlerini artırmıştır. Türkiye'de yapılan çalışmalar incelendiğinde matematik eğitimine ilişkin 2002 yılından sonra (Çiltaş, Güler ve Sözbilir, 2012); okul öncesi dönemde matematik eğitimi üzerine yapılan araştırmalarda ise 2004 yılından itibaren (Bağcı ve İvrendi, 2016) büyük bir artış olduğu görülmektedir. Ayrıca 2000 yılından sonra YÖK ulusal tez merkezinde matematik eğitimi alanında yapılmış yaklaşık 500 yüksek lisans ve doktora tezine ulaşım imkanı sağlanabilmektedir (Baki, Güven, Karataş, Akkan ve Çakıroğlu, 2011). Sürekli olarak değişim ve gelişim gösteren dünyada toplumun ihtiyaçlarına cevap verecek nitelikte insanların eğitilmesi, eğitim alanında yapılan bilimsel araştırmalar ile mümkün olabilmektedir. İçinde yaşanılan yeni yüzyıl, somut düşünme, öğrenme, öğretme, ezber- 
leme yeteneğinin ötesinde yaratıcı zihinsel yeteneklerin geliştirilmesini, mantıklı düşünmeyi, problem çözebilme yeteneklerini öne çlkarmaktadır (Kayhan ve Özgün Koca, 2004; Yücedağ ve Erdoğan, 2011). Dolayısıyla teknolojinin hakim olduğu bu yüzyılda fen bilimleri ve matematik alanlarında daha fazla bilimsel araştırma ve sorgulama yapılması gerekliliği ortaya çıkmaktadir.

Matematik eğitimi ile ilgili son yıllarda yapılan araştırmaların incelenmesi; araştırmacılar, eğitimciler ve öğretmenlere bilimsel tartışma ve sorgulama yapma fırsatı sunmaktadır. Çünkü araştırmaların belirli aralıklarla incelenerek eğilimlerinin belirlenmesi, ilgili alanda çalışma yapacak olan araştırmacılara ışık tutması açısından önemli görülmektedir (Cohen, Manion ve Morrison, 2007). Yapılan literatür taraması sonucunda yurt dışında matematik eğitimi alanında yapılan araştırmaların sentezlendiği çalışmalara rastlanmaktadır (Hart, Smith, Swars ve Smith, 2009; Lubiensky ve Bowen, 2000). Matematik ile ilgili yapılan bu sentez araştırmalarının 1982-2005 yılları arasındaki çalışmaları kapsadığı ve bu araştırmaların çoğunlukla nitel araştırma olduğu ve genelde ilköğretim kademesindeki çocuk ve uygulamaları kapsadığı görülmektedir. Bu konuda Türkiye'de yapılan çalışmalar incelendiğinde (Bağcl ve İvrendi, 2016; Baki, Güven, Karataş, Akkan ve Çakıroğlu, 2011; Çiltaş, Gürsel ve Sözbilir, 2012; İnceoğlu, 2009; Kayhan ve Özgün Koca, 2004; Ulutaş ve Ubuz, 2008; Yücedağ ve Erdoğan, 2011) yurt dışındakilere benzer olarak çalışma kapsamının daha çok ilköğretim kademesine dönük olduğu; sadece çalışmalardan birisinde (Bağcı ve İvrendi, 2016) okul öncesi dönemde 2000-2015 yılları arasında matematik eğitimini konu alan makalelerin incelendiği bilinmektedir. Dolayısıyla son beş yılda yayımlanan makale ve lisansüstü tezlerin sentezlendiği bir çalışmaya rastlanılmamıştır.

$\mathrm{Bu}$ araştırma, literatürde yer alan diğer sentez araştırmalarına kıyasla son yedi yılda okul öncesi eğitimde matematik ile ilgili yapılmış olan hem bilimsel makale araştırmaları hem de lisansüstü tezleri içermesi yönünden farklılık göstermektedir. Ayrıca bu çalışmada ele alınan araştırmalar önceki araştırmalara karşın sistematik bir form çerçevesinde incelenmiştir. Dolayısıyla bu araştırmanın literatürdeki diğer çalışmalara göre daha güncel ve daha sistematik bilgi sunması ve sonrasında yapılacak olan bilimsel araştırmalara ışık tutması yönüyle alana katkı sağlayacağı düşünülmektedir. 


\section{Araştırmanın Amacı}

Araştırmanın amacı, Türkiye'de okul öncesi dönemde matematik eğitimi ile ilgili 2012-2019 yılları arasında yapılan lisansüstü tezler ve bilimsel makalelerin incelenmesidir. Bu amaç doğrultusunda aşağıdaki alt problemlere cevap aranmıştır:

Okul öncesi dönemde matematik eğitimi ile ilgili çalışmaların,

- Türlerine göre dağılımı nedir?

- Yayınlandıkları yıllara göre dağılımı nedir?

- Yer aldığı dergilerin tarandığı indekslere göre dağılımı nedir?

- Konularına göre dağılımı nedir?

- Araştırma yöntemleri/desenlerine göre dağılımı nedir?

- Kullandığı veri toplama araçlarına göre dağılımı nedir?

- İçerdiği örnekleme yöntemlerine göre dağılımı nedir?

- İçerdiği veri analiz tekniklerine göre dağılımı nedir?

\section{Yöntem}

\section{Araştırma Deseni}

Bu araştırma; Türkiye'de okul öncesi dönem matematik eğitimi ile ilgili yapılan çalışmaların bir sentezini ortaya koyduğundan betimsel nitelikte olup, nitel araştırma deseninde kurgulanmıştır. Nitel araştırmalar, gözlem, görüşme ve doküman analizi gibi nitel veri toplama teknikleri kullanılarak alg1 ve olayların doğal ortamlarında gerçekçi ve bütüncül bir şekilde ortaya konmasına yönelik bir sürecin izlendiği araştırmalar olarak açiklanmaktadır (Yıldırım ve Şimşek, 2013, s.39) Birebir etkileşim gerektirmeyen daha çok dokümanlara dayalı veri toplama ve analiz esasına dayalı etkileşimsiz nitel araştırma deseni kurgusunda oluşturulan bu çalışmada (Karasar, 2005), okul öncesi dönemde matematik eğitimi üzerine yapılan araştırmalar konusunda bir durum tespiti yapılmaya çalışılmıştır.

\section{Çalışma Grubu}

Araştırmada, okul öncesi dönemde matematik eğitimi ile ilgili son yıllarda yapılan araştırmaların incelenmesinin gelecekte yapılacak araştırmalara ışık tutacağı görüşünden hareketle (Cohen, Manion ve Morrison, 2007), ilgili ça- 
lışmaların seçilmesi için belli özelliklere sahip olgu, olay ve durumların seçilerek bunların derinlemesine keşfedilmesi ve açıklanması amacını güden amaçlı örnekleme yöntemi tercih edilmiştir (Büyüköztürk, Kılıç-Çakmak, Erkan-Akgün, Karadeniz ve Demirel, 2018). Bu bağlamda ilgili araştırmaların seçilmesi için çeşitli ölçütler belirlenmiştir. Bunlar; okul öncesinde matematik eğitimi alanında son yedi yıl içerisinde yayınlanmış olması, araştırmacılardan en az birinin Türk olması, Türkiye'de Haziran 2012 ve Mart 2019 tarihleri arasında yayımlanan okul öncesinde matematik eğitimine ilişkin lisansüstü tezler ile ulusal ve uluslararası indekslerde taranan dergilerde Türkçe veya İngilizce olarak yayımlanmış araştırma makaleleri olmasıdır. Belirtilen ölçütlere uygun olarak yapılan literatür taraması sonucunda okul öncesi dönemde matematik eğitimini konu alan toplam 131 çalışmaya ulaşılmıştır. Bu çalışmalardan 47'si lisans üstü tezler iken 84'ü makalelerden oluşmaktadır. Ulaşılan 16 makalenin (11'i yüksek lisans tezinden 5'i doktora tezinden üretilmiştir) lisansüstü tezlerden üretilmesi nedeniyle bu makalelerin üretildikleri tezler araştırmaya dahil edilmemiştir. Dolayısıyla araştırma kapsamında toplam 115 çalışma incelenmiştir.

\section{Verilerin Toplanmast}

Araştırmada, veri toplama tekniği olarak doküman incelemesinden yararlanılmıştır. Nitel araştırmalarda veri toplamada kullanılan dokümanlar; toplumsal kayıtlar, bireysel yazılar, popüler kültür dokümanları, sanat eserleri gibi insan yapımı yazılı ve görsel materyaller olarak tanımlanmaktadır (Merriam, 2015). Literatür incelendiğinde 2015 yllına kadar okul öncesi matematik eğitimine ilişkin çalışmaların irdelendiği (Bağcı ve İvrendi, 2016) görülmekle birlikte özellikle lisansüstü eğitimde yeni tamamlanan tezlerin YÖK'ün tez kataloğuna girmesinin oldukça uzun sürdüğü bilinmektedir. Bu nedenle mümkün olduğunca yapılan bütün çalışmalara ulaşılması amacıyla araştırmacılar, incelenecek çalışmaların 2012 yılından başlanmasına karar vermişlerdir. Bu bağlamda araştırmada doküman olarak okul öncesi matematik eğitimi alanında Haziran 2012-Mart 2019 tarihleri arasında yapılan lisansüstü tezlerle ulusal ve uluslararası hakemli dergilerde yayımlanmış araştırmalar temel alınmıştır.

Çalışmaya dahil edilen araştırmaları incelemek üzere araştırmacılar tarafından çalışmanın amacına yönelik Çiltaş, Güler ve Sözbilir (2012) tarafından 
geliştirilen "Makale Sınıflama Formu" temel alınarak bir "Araştırma İnceleme Formu" hazırlanmıştır. Bu noktada Çiltaş vd. (2012)'nin çalışmalarında da belirttikleri üzere her farklı alanda yapılan çalışma için bazı düzenlemeler yapılması gerektiği görüşünden hareketle formda yer alan "Makalenin alanı" alt başlığ çıkarılarak taslak bir form oluşturulmuştur. Bunlara ek olarak "Her bir araştırmacı tarafından bu taslak formun değerlendirmeye uygun olup olmadığını belirlemek amacıyla çalışma grubundan rastgele seçilen 20 araştırma için form ayrı ayrı doldurularak incelenmiştir. Ardından araştırmacılar bir araya gelerek formun yeniden düzenlenmesi için görüşmüştür. Görüşme sonucunda formun son haline ve nasıl doldurulması gerektiğine karar verilmiştir. Formdaki alt başlıklarda ve formun doldurulma şeklinde değişiklikler yapılmıştır. Örnekleme alt başlığına “Örnekleme yöntemi” ve veri analiz türü alt başlı̆̆ına ise "Veri analiz programı" maddeleri de eklenmiştir. Ayrıca "Makalenin konusu", "Araştırma yöntemi" ve "Veri toplama araçları" alt başlıkları seçenekler halinde yapılandırılmamış olup detaylı olarak açıklanacak şekilde yeniden düzenlenmiştir. Araştırmacılar tarafından geliştirilen bu formda araştırmanın künyesi (yazarı, yayınlandığı tarih, yayınlandığı dergi/enstitü adı, derginin tarandığı indeks), konusu, deseni, veri toplama araçları, örnekleme yöntemi, örneklem/çalışma grubu, örneklem sayısı ve veri analiz türü hakkında bilgilerden oluşmaktadır.

Hazırlanan "Araştırma İnceleme Formu", belirlenen ölçütler doğrultusunda her araştırmacı tarafından doldurulmuştur. Verilerin formlara işlenmesi sürecinde belirlenen ölçütler temel alınmakla birlikte Yüksek Öğrenim Kurulu (YÖK) tez veri tabanındaki erişime açık olmayan tezler ve ücretli dergilerde yayınlanan makaleler çalışmaya dahil edilmemiştir. Taramalar sonucunda tezlerden üretilmiş makalelere rastlanılmış ve bu tezlerin sadece makaleleri çalışma kapsamında değerlendirilmiştir. Bunların yanı sıra ulaşılan derleme makaleler çalışma grubundan çıkarılmış, çalışma kapsamında sadece araştırma makalelerine odaklanılmıştır. Çalışmaya dahil edilen araştırmaları belirlemek için YÖK Tez, ULAKBİM, SBVT, YÖK Akademik, Araştırmax, DOAJ, ERIC, Web of Sience, EBSCO, Asos İndeks Copernicus, Türk Eğitim İndeksi veri tabanlarında ve Dergi Park'ta yer alan "eğitim" kategorisindeki her bir dergide literatür taraması yapılmıştır. Taramalar "okul öncesi dönemde matematik", "erken çocukluk eğitiminde matematik", "okul öncesi eğitim ve matematik" ve "erken çocukluk eğitimi ve matematik" anahtar ke- 
limeleri kullanılarak yapılmıştır. Taramalar yapılırken veri tabanlarının gelişmiş tarama kısımlarına anahtar kelimeler girilmeden önce aramanın çalışmaların tamamında (başlık, özet, konu, dizin) taratılması ve 2012 ile 2019 yılları arasında olması seçenekleri işaretlenmiştir. Ulaşılan çalışmalar, yazarların soyadları ve yayım yılı belirtilerek kodlanmış ve kaydedilmiştir.

Geniş bir tarama olması nedeniyle bir çalışmaya birden fazla veri tabanında rastlanılmıştır. Çalışmaların künyelerinin kodlanması aynı çalışmanın tekrar tekrar kaydedilmesini engellemiştir. Kaydedilen araştırmalar, araştırmacılar tarafından detaylı bir şekilde incelenmiş ve her bir çalışma için her bir araştırmacı tarafından "Araştırma İnceleme Formu" doldurulmuştur. Tüm çalışmalara ilişkin bilgiler forma aktarıldıktan sonra elde edilen veriler Excel dosyasında toplanmıştır. Excel sayfasında formda yer alan her kategori için bir sütun açılmış ve çalışmalara ilişkin bilgiler bu dosya üzerinde kodlanarak kaydedilmiştir.

\section{Verilerin Analizi}

Araştırma verileri tümevarımsal içerik analizi yaklaşımıyla çözümlenmiştir (Patton, 2002). Tümevarımsal içerik analizi yaklaşımında temalar ve kategoriler kaynağını veri setinden almaktadır (Zhang ve Wildemuth, 2009). Bir başka deyişle, kodlar katılımcıların ifadelerinden ortaya çımakta ve anlam kümeleri oluşturmaktadır. Birbirine benzeyen veriler bir araya getirilerek ele alınmakta ve verilere ilişkin belgeler sistematik bir biçimde incelenerek analiz edilmektedir (Yıldırım ve Şimşek, 2013). Bu bağlamda öncelikle veri analizi sürecinde araştırmacılar bir araya gelmiş, her bir araştırmacının doldurduğu form incelenerek ortak bir görüş oluşturmak amacıyla verilerin tekrar tekrar okunmasını takiben, açık kodlamalar yapılmıştır. Daha sonra kodlar arası ilişkiler gözden geçirilerek kategoriler oluşturulmuştur. Bir başka deyişle araştırmacılar, gerek verilerin toplanması ve verilerin analizi gerekse elde edilen bulguların yorumlanmasında birlikte çalışarak süreci birlikte yönetmişlerdir.

Verilerin analizi sürecinde MS Office Excel programı kullanılarak frekans ve yüzdeler belirlenmiştir. Araştırmada incelenen makalelerin indeksleri incelenirken Üniversitelerarası Kurul'un 2019 yılı Eğitim Bilimleri ve Öğretmen Yetiştirme Temel Alanına (Doçentlik Başvuru Şartları, 2019) ilişkin doçentlik 
kriterleri dikkate alınmıştır. İncelenen bu araştırmalarda araştırmacıların beyanları esas alınmıştır. Bu bağlamda araştırmacılar herhangi bir ekleme veya yorum yapmamış olup elde edilen veriler daha çok niceliksel olarak belirlenmiştir. Bununla birlikte araştırmalar incelenirken konu, örnekleme yöntemi, örneklem/çalışma grubu ve veri toplama araçları araştırmalarda birden çok kez belirlendiği için bu başlıklar altındaki araştırma sorularına yönelik incelemelerde araştırma sayısı yerine belirtilen özelliğin sayısı dikkate alınmıştır. Buna karşın bazı araştırmalarda araştırma metodu ve/veya örnekleme yöntemi, veri analizi yöntemi net olarak belirtilmediği için analizlerde de bunlar dikkate alınmamıştır. Bununla birlikte araştırmada bütünlük sağlaması ve anlaşılırlığı kolaylaştırmak amacıyla incelenen çalışmaların konu sınıflaması temel alınarak veri toplama araçları ve örneklem/çalışma grubuna ilişkin analizler gerçekleştirilmiştir. Elde edilen bulgular tablo ve grafikler üzerinde gösterilerek yorumlanmıştır.

\section{Geçerlik ve Güvenirliğin Sağlanması}

Nitel araştırmalarda geçerlik kullanılan veri toplama aracının, gerçekleştirilen işlemlerin ve verilerin uygunluğunu ifade ederken; güvenirlik ise çalışmanın tutarlılığı hakkında bilgi vermektedir (Creswell, 2017). Araştırmada, geçerliğin sağlanmasında inandırıcılık, aktarılabilirlik ve teyit edilebilirlik; güvenirliğin sağlanmasında tutarlılık stratejilerine başvurulmuştur (Lincoln ve Guba, 1985). Araştırmada inandırıcılığı sağlamak için ele alınabilecek stratejilerden araştırmacı üçgenlemesi ile derinlik odaklı veri toplama kullanılmıştır. Araştırmada gerek veri toplama süreci, veri analizinde gerekse bulguların ortaya konmasında üç araştırmacının da matematik eğitimi alanında çalışmalarının olması süreci birlikte yönetmeleri elde edilen verileri anlamlandırmayı kolaylaştırmakla birlikte aynı zamanda araştırmacıların elde edilen verilerle uzun süreli etkileşimde bulunmaları sonucu önyargılardan uzak olmalarına da yardımcı olmuştur (Creswell, 2017; Merriam, 2015; Patton, 2014; Yıldırım ve Şimşek, 2013). Bununla birlikte nitel araştırmaların aktarılabilirliğinin sağlanması için detaylı bir şekilde betimleme ve amaçlı örnekleme kullanılması önerilmektedir (Lincoln ve Guba, 1985; Yıldırım ve Şimşek, 2013). $\mathrm{Bu}$ araştırmada ele alınan araştırmaların özellikleri, veri toplama, veri analiz süreci ve bulgular ayrıntılı bir şekilde betimlenerek çalışmanın aktarılabilirliği sağlanmaya çalışılmıştır. Nitel araştırmalarda teyit edilebilirlik stratejisi 
araştırmanın verilerinin dış denetime açık olması gerektiği anlamına gelmektedir. Bu şekilde uzmanlar araştırmayı denetleyebilme ve inceleme imkânına sahip olurlar (Creswell, 2017). Bu araştırmada teyit edilebilirliği sağlamak ve verileri saklamak için araştırmanın tüm verileri ve aşamaları bilgisayar ortaminda saklanmıştır.

Nitel araştırmalarda güvenirliği sağlamak için birden fazla araştırmacının veri setlerini kodlayarak, kodlar arasındaki tutarlılığın sağlanması gerektiği belirtilmektedir (Lincoln ve Guba, 1985). Bu araştırmada ele alınan çalışmalar araştırmacılar tarafından ayrı ayrı kodlanmıs ve kodlayıcılar arasındaki tutarllık incelenmiştir. Veri analizinin güvenirliğini Miles ve Huberman'ın (1994) Uzlaşma Yüzdesi=[Görüş birliği/ (Görüsş birliği + Görüş ayrılığı) X 100] formülü kullanılarak sınanmıştır. Buna göre kodlayıcılar arasındaki uzlaşma yüzdesi .95 olarak bulunmuştur. Kodlayıcılar arası uyum oranın .70'ten yüksek olması halinde kodlamalarının güvenilir olduğunu söylenebilir (Creswell, 2017). Ayrıca farklı kodlamaların olduğu durumlarda araştırmacılar tarafından görüş birliğine varılarak kodun ne olacağına karar verilmiştir.

\section{Bulgular}

Bu araştırma, Türkiye'de 2012-2019 yılları arasında okul öncesi dönem matematik becerileri ve eğitimi ile ilgili yapılan makalelerin ve lisansüstü tezlerin incelenmesi amacıyla yapılmıştır ve bu bağlamda elde edilen bulgular araştırma soruları doğrultusunda aşağıda sıralanmıştır. İlk olarak çalışma grubuna dâhil edilen çalışmaların türlerine göre dağılımı Şekil 1'de verilmiştir.

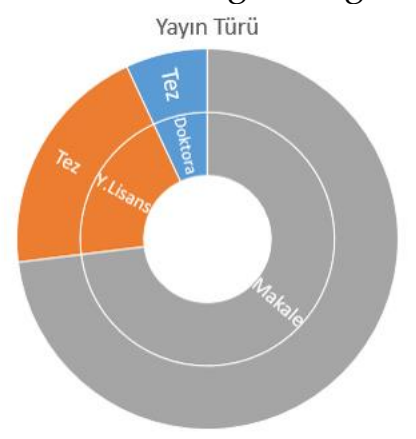

Şekil 1. Okul öncesi dönemde matematik eğitimi ile ilgili çalışmalarnn yayın türlerine göre dağılımı 
Şekil 1' de görüldügüü gibi incelenen araştırmaların büyük bir kısmı makale

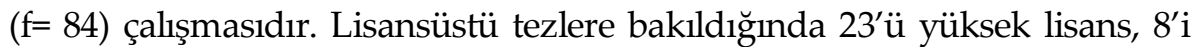
doktora tezi olmak üzere toplam 31 tez çalışması bulunmaktadır. Çalışmaların yayınlandıkları yıllara göre dağılımı Şekil 2'de verilmiştir.

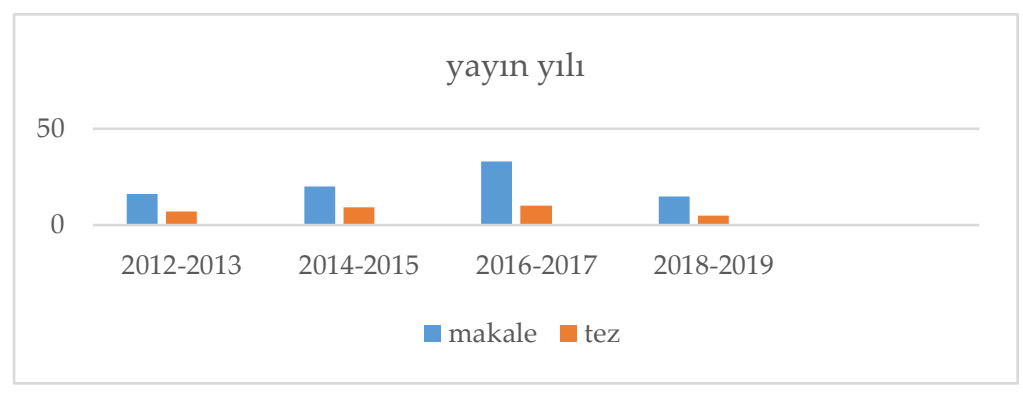
Şekil 2. Okul öncesi dönemde matematik eğitimi ile ilgili çalışmaların yayınlandıklan yıllara göre dağılımı

Şekil 2'de araştırmaya dahil edilen çalışmaların yayımlandıkları yıllara göre dağılımı incelendiğinde, hem makaleler hem de tezler açısından 2012 yılından başlayarak 2018 yılına kadar çalışmaların düzenli bir artış gösterdiği ancak, 2018-2019 yıllarında belirgin bir düşüş olduğu görülmektedir. Araştırmada incelenen makalelerin yer aldığı dergilerin tarandığ 1 indekslere göre dağılımı Şekil 3'te verilmiştir.

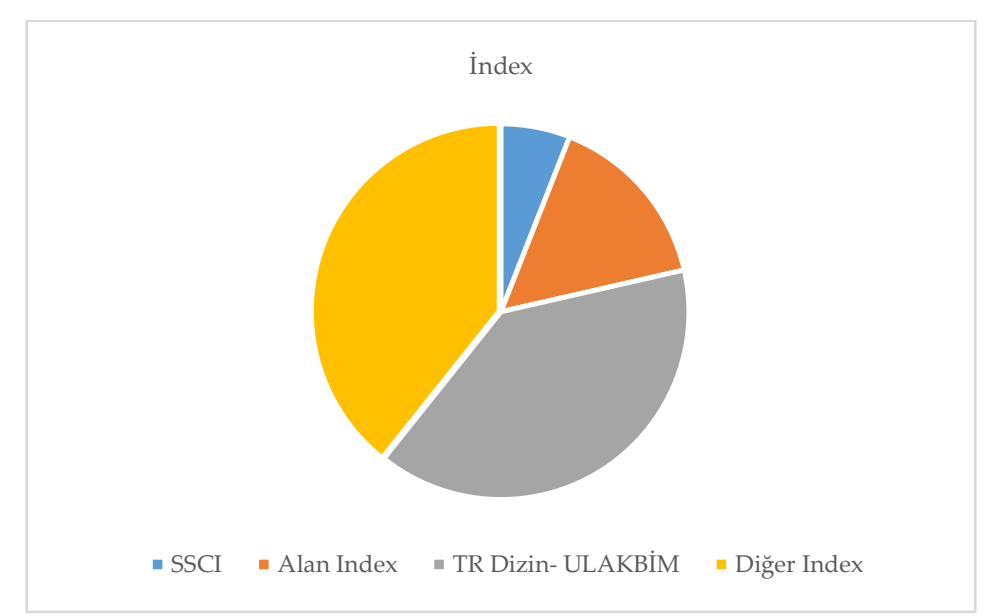

Şekil 3. Okul öncesi dönemde matematik eğitimi ile ilgili makalelerin yer aldı̆̆ı dergilerin tarandığı indekslere göre dağılımı 
Şekil 3'te görüldüğü gibi araştırmaya dahil edilen makalelerin yayınlandığı dergiler çoğunlukla ULAKBİM ( $\mathrm{f}=33$ ) ve diğer indeks kategorisinde $(\mathrm{f}=33)$ taranmaktadır. Makaleler $(\mathrm{f}=84)$ arasında en az SSCI'da taranan makaleler yer almaktadır ( $\mathrm{f}=5)$. Bu bağlamda incelenen çalışmaların daha çok ulusal indeksli dergilerde yayımlandığı görülmektedir. Çalışmaların konularına göre dağılımı Şekil 4' te verilmiştir.

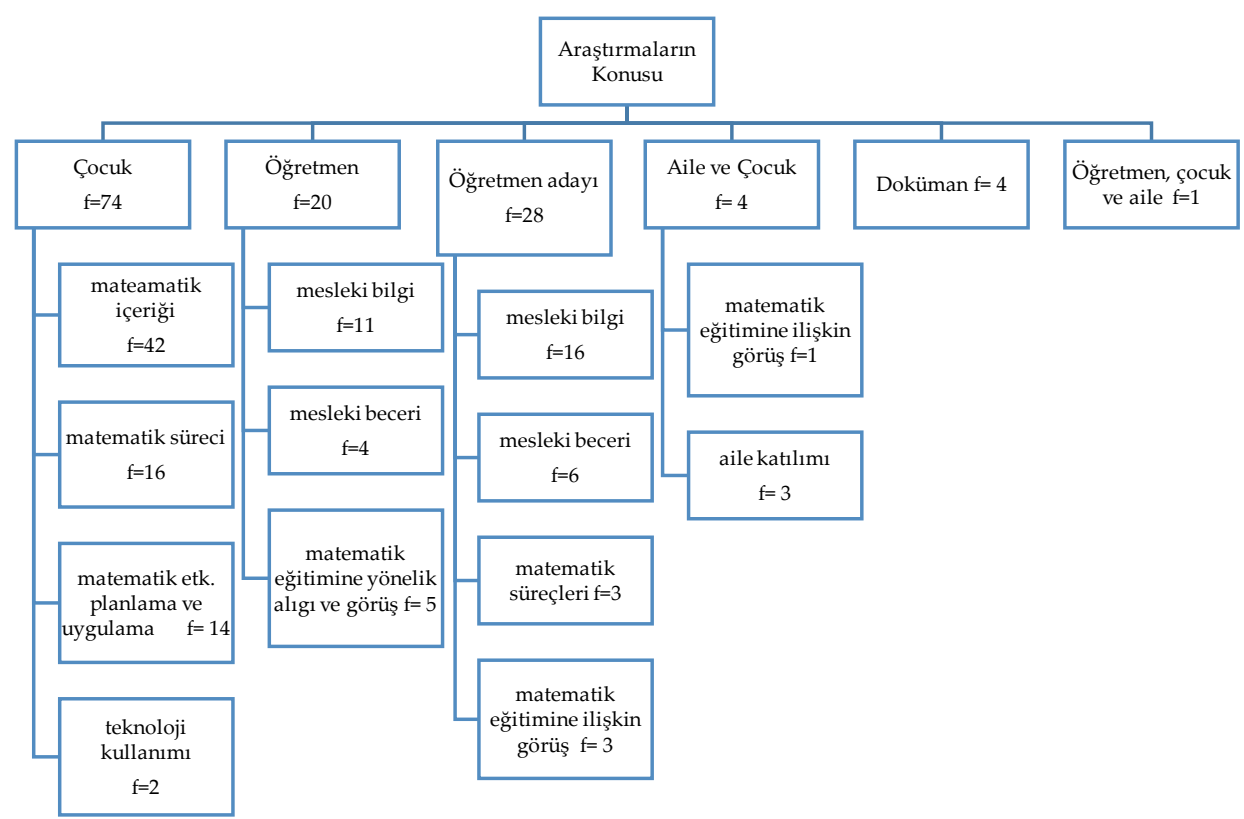

Şekil 4. Okul öncesi dönemde matematik eğitimi ile ilgili çalışmalarnn konularnna göre dă̆ılımı

Şekil 4'ten de anlaşılacağı üzere incelenen çalışmaların konularının en çok çocuklarla ( $\mathrm{f}=74$ ) ilgili olduğu ardından sırasıyla öğretmen adayı ( $\mathrm{f}=28)$; öğretmen $(\mathrm{f}=20)$, doküman inceleme $(\mathrm{f}=4)$; aileler ve çocuklar $(\mathrm{f}=3)$; çocuk, aile ve öğretmenlerin ( $\mathrm{f}=1$ ) birlikte ele alındığı çalışmaların yer aldığı görülmektedir. Bir araştırma birden fazla konu içerebildiği için içerik analizinde belirtilen konu sayısı dikkate alınmıştır. Yapılan araştırmalar incelendiğinde belirtilen konular birbiri ile olan ilişkileri bakımından kategorize edilmiş ve sonuçta çocuklarla ilgili konularda NCTM'nin (2000) matematik eğitimi standartları, öğretmen ve öğretmen adayları ile ilgili yapılan çalışmalarda MEB tarafından 
Türkiye Yeterlikler Çerçevesi (MEB, 2017) bağlamında hazırlanan öğretmenlerin genel yeterlikleri temel alınmıştır. Aile ve çocuk, aile, öğretmen ve çocuk ile doküman kategorisinde incelenen çalışmaların sayısının az olması nedeniyle herhangi bir kategorizasyon yapılmamıştır. Çocuklara ilişkin olarak belirtilen konuların 42'sinin matematiğe ilişkin çocuklara sunulacak içerikle (sayı ve işlem, cebir, geometri, ölçme, veri analizi ve olasık), 16'sının matematik süreçleri (problem çözme, akıl yürütme, iletişim, ilişkilendirme ve gösterim), 14'ünün matematik etkinlikleri planlama ve uygulama, 2'sinin ise teknoloji kullanma ile ilgili olduğu belirlenmiştir. Öğretmenlerle ile ilgili belirtilen konulardan $11^{\prime}$ inin mesleki bilgi, 4 'ünün mesleki beceri, 5 'inin de matematik eğitimine yönelik alg1/görüşle ilgili kategorilere ilişkin olduğu bulunmuştur. Öğretmen adayları ile ilgili belirtilen konuların ise 16'sını mesleki bilgi, 6'sını mesleki beceri, 3'ünü matematiksel süreç ve 3'ünü matematik eğitimine ilişkin görüşlerine ilişkin kategoriler oluşturmuştur. Aileler ile birlikte çocukları konu alan çalışmalar incelendiğinde birinin ebeveynlerin matematik eğitimine ilişkin görüşleri diğer 3 'ünün matematik eğitimde aile katılımına ilişkin olup bu çalışmaların tamamının çocukların matematik becerilerindeki gelişimlerini içerdiği; öğretmen, aile ve çocukları birlikte ele alan bir çalışmada da öğretmenlerin matematiğe ilişkin kaygı ve inançları ile çocukların sayı kavramına ilişkin gelişimleri ve ebeveynlerin matematik etkinliklerine katılımı ile ilgili konular yer almıştır. Doküman kategorisinde okul öncesi eğitime ilişkin lisans ve okul öncesi dönem çocukları için hazırlanmış programın ve hikaye kitaplarının incelemesi ile ilgili konuların yer aldığ1 belirlenmiştir. Çalışmaların araştırma yöntemleri/desenlerine göre dağılımı Şekil 5'te verilmiştir. 


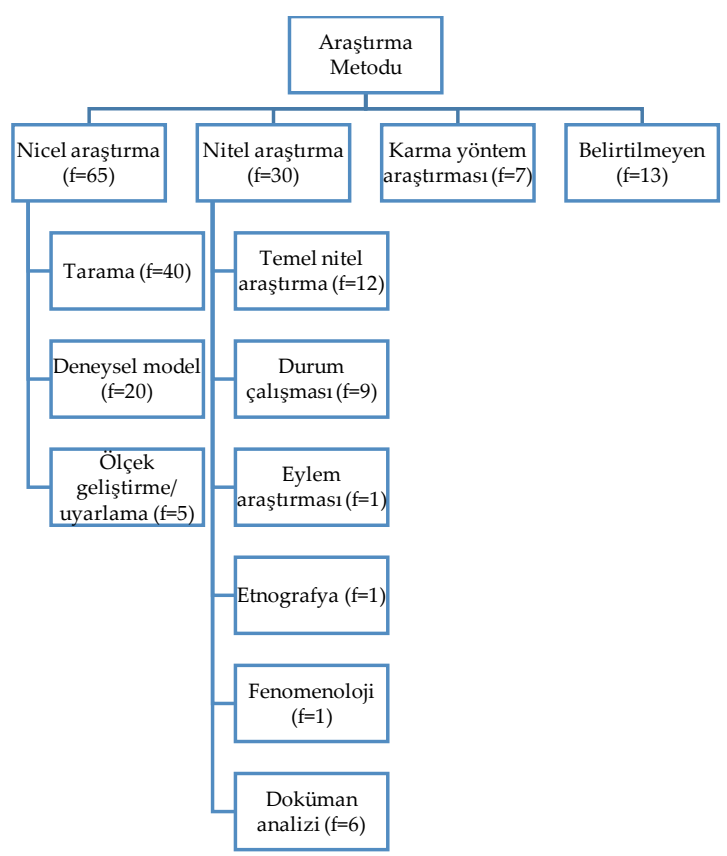

Şekil 5. Okul öncesi dönemde matematik eğitimi ile ilgili çalışmalarn araştırma yöntemleri/desenlerine göre dağılımı

Şekil 5'ten de anlaşılacağı üzere araştırmaya dahil edilen çalışmaların büyük çoğunluğunun nicel araştırma metodolojisi ile yürütüldügü görülmektedir. Diğer yandan nitel araştırma metodolojisi ile yürütülen çalışmaların genellikle temel nitel araştırma veya durum çalışması desenlerinde yapıldığı görülürken ( $\mathrm{f}=21)$ yedi çalışmada da karma yöntem kullanıldığı belirlenmiştir. Ayrıca 13 çalışmada araştırma metodunun belirtilmediği tespit edilmiştir.

Araştırmada kullanılan veri toplama araçları daha önce konularla ilgili yapılan sınıflama doğrultusunda ele alınmış ve bu bağlamda elde edilen bulgular Şekil 6' da sunulmuştur 


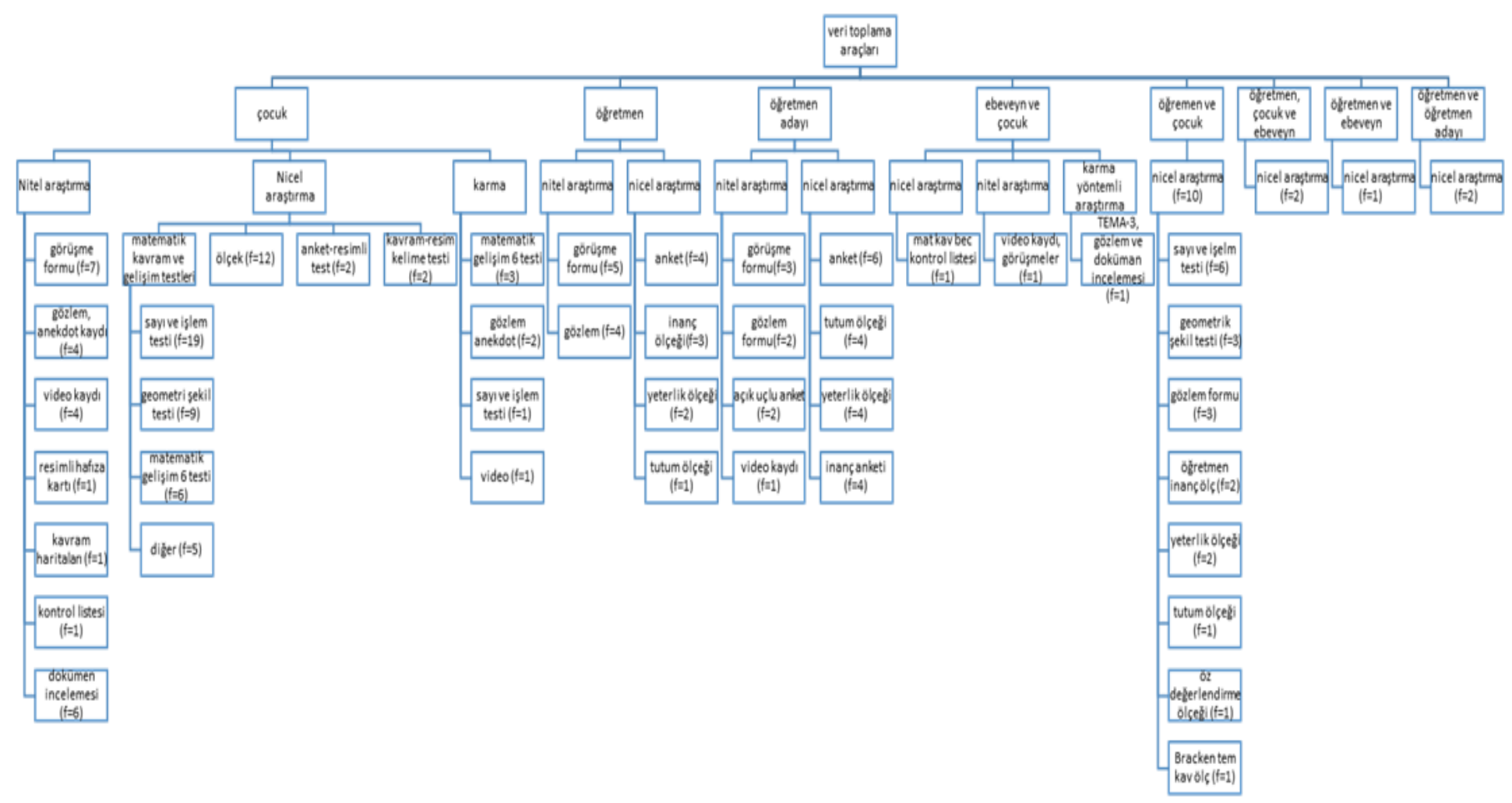

Şekil 6. Okul öncesi dönemde matematik eğitimi ile ilgili çalışmalarda kullanilan veri toplama araçlarna göre dağı̆lım

OPUS (C) Uluslararası Toplum Araştırmaları Dergisi • 633 
Örneklem/çalışma grubu çocuklardan oluşan çalışmalarda kullanılan veri toplama araçları araştırma yöntemine göre sınıflandırılmıştır. Şekil $6^{\prime}$ da da görüldüğ ü gibi örneklemi çocuklar olan çalışmalarda nicel araştırma yönteminde kullanılan veri toplama araçlarına daha sık yer verilmiştir. Çocuklar ile yapılan çalışmalarda kullanılan nicel veri toplama araçları "matematik kavram testi" kategorisi altında toplanmıştır. Bu veri toplama araçları, çocukların sayı ve işlem becerilerini ölçmeyi amaçlayan "5-6 Yaş Çocukları için Sayı ve İşlem Kavramları Testi”, "5-6 Yaş Çocuklarda Sayı ve Işlem Kavramlarının Kazanılmasına İlişkin Başarı Testi", "Erken Sayı Değerlendirme Ölçeği”, "Sayma İlkeleri Testi" gibi testlerdir. Bu testlerin yanı sıra geometri ve şekilleri tanıma testleri de bu kategori altında belirtilmiştir. "Geometri ve Uzaysal Algı Testi”, "Geometrik Şekilleri Tanıma Testi”, "48-86 Aylık Çocuklar için Sayı ve Şekil Kavram Testi”, "Erken Geometri Beceri Testi” çocukların geometri becerilerini ölçmek için kullanılan veri toplama araçlarıdır. Diğer kategorisi içerisinde değerlendirilen veri toplama araçları ise "Erken Matematik Akıl Yürütme Becerileri Değerlendirme Aracı", "Temel Okul Becerileri Envanteri Matematik ve Günlük Yaşam Becerileri Alt Testi" dir. Ölçek kategorisine çocukların matematiksel içerik ve süreç becerilerini değerlendirmeye yönelik olan "Erken Öğrenme Becerileri Değerlendirme Ölçeği”, "Matematik İçerik Standartları Ölçeği”, " Problem Çözme Becerileri Ölçeği”, "Matematiği Sevme Ölçeği" dahil edilmiştir. Nitel araştırma metodolojisi ile yürütülen çalışmalara bakıldığında kullanılan veri toplama araçları çocuk ile doğrudan veri elde edilmesini sağlayan gözlem formu, video kayıtları ve görüşme formlarıdır.

Örneklem/çalışma grubunun öğretmenlerden oluştuğu çalışmalarda kullanılan veri toplama araçları incelendiğinde Şekil 6'da görüldüğü gibi örneklem/çalışma grubu öğretmenlerden oluşan çalışmalarda da nicel veri toplama araçlarına daha sık yer verildiği görülmektedir. Bu ölçme araçları genellikle öğretmenlerin matematik eğitimine ilişkin tutum, inanç ve özyeterliklerini belirlemeye yöneliktir. “Okul Öncesi Öğretmenliği Okul Öncesi Dönem Matematik Eğitimine Yönelik Özyeterlik Ölçeği” öğretmenlerin yeterliklerini ölçmeyi amaçlayan çalışmalarda kullanılan veri toplama aracıdır. Anket kategorisinde yer alan veri toplama araçları ise "Okul Öncesi Programda Matematik Eğitimi Değerlendirme Öğretmen Formu”, “Okul Öncesi Öğretmenlerinin Programda Matematik Eğitimi için Ayırdıkları Süre ve Görüşlerini De- 
ğerlendirme Formu" ve "Veri Toplama Anketi"dir. Bunların yanı sıra öğretmenlerin matematik eğitimine ilişkin inançlarını ölçmek için kullanılan veri toplama araçları, "Matematiksel Gelişim İnanç Ölçeği", "Matematik Öğretimine Yönelik İnanç Ölçeği"dir. Nitel araştırma metodolojisi ile yürütülen çalışmalarda ise öğretmenlerin görüşlerini almaya yönelik görüşme formları ve matematik etkinlikleri sırasında öğretmenlerin gözlemlenmesi için gözlem formları kullanılmıştır.

Öğretmen adayları ile yapılan çalışmalarda kullanılan veri toplama araçlarına bakıldığında Şekil 6' da görüldüğü gibi nicel araştırmalarda kullanılan veri toplama araçlarının yoğunlukta olduğu görülmektedir. Öğretmenler ile yapılan çalışmalara kıyasla öğretmen adayları ile olan nitel çalışmalarda daha çeşitli veri toplama araçlarının kullanıldı̆̆ı söylenebilir. Öğretmen ve çocuk örneklem/çalışma grubunda yapılan nicel çalışmalarda kullanılan veri toplama araçları değerlendirildiğinde, çocukların matematiksel kavram ve işlem becerilerinin ölçüldüğü ve bu sonuçların öğretmenlerin matematik eğitimine ilişkin tutum, inanç, yeterlik ve öz değerlendirmeleri ile karşılaştırıldığı görülmektedir. Ebeveyn ve çocuk örneklem/çalışma grubunda yapılan çalışmalarda kullanılan veri toplama araçları değerlendirildiğinde ise Şekil 6'da görüldüğü gibi çocukların matematik becerilerinin ölçülmesinin yanı sıra ebeveynlerin görüşlerine ve gözlem kayıtlarına da yer verilmiştir.

Örneklem/çalışma grubu çocuk, ebeveyn ve öğretmenlerden oluşan iki nicel araştırmada, "Matematik Etkinliklerine Yer Verme Durum Ölçeği”, "5-6 Yaş Çocuklarda Sayı ve İşlem Kavramlarının Kazanılmasında İlişkin Başarı Testi”, “Okul Öncesi Öğretmenlerinin Okul Öncesi Matematiğine İlişkin Tutumlarını Belirleme Aracı", "Anne Babaların Matematik Etkinliklerine Katılım Ölçeği" kullanılmıştır. Örneklem/çalışma grubu öğretmen ve öğretmen adaylarından oluşan iki çalışma ise nicel araştırma metodolojisi ile yürütülmüştür. Veri toplama aracı olarak da "Okul Öncesi Matematiğinde Pedagojik Alan Bilgisi Ölçeği”, "Matematik Endişe Ölçeği” kullanılmıştır. Son olarak öğretmen ve ebeveynlerin örnekleme/çalışma grubuna alındığı nitel bir araştırmada Delphi tekniği açık uçlu soruların bulunduğu bir anket veri toplama aracı olarak kullanılmıştır. Çalışmalarda kullanılan veri toplama araçları genel olarak değerlendirildiğinde en çok çocukların matematiksel kavram ve becerilerini ölçmeye yönelik araçların kullanıldığı görülmektedir. Ancak bu değerlendirme araçlarının çoğunlukla uyarlama çalışmaları sonucunda alana kazandırıldığı görülmüş Türk çocuklar ile geliştirilen ölçme araçlarının sınırlı 
sayıda olduğu belirlenmiştir. Araştırma kapsamında incelenen çalışmaların içerdiği örneklem/çalışma grubuna göre dağılımı Şekil 7'de sunulmuştur.

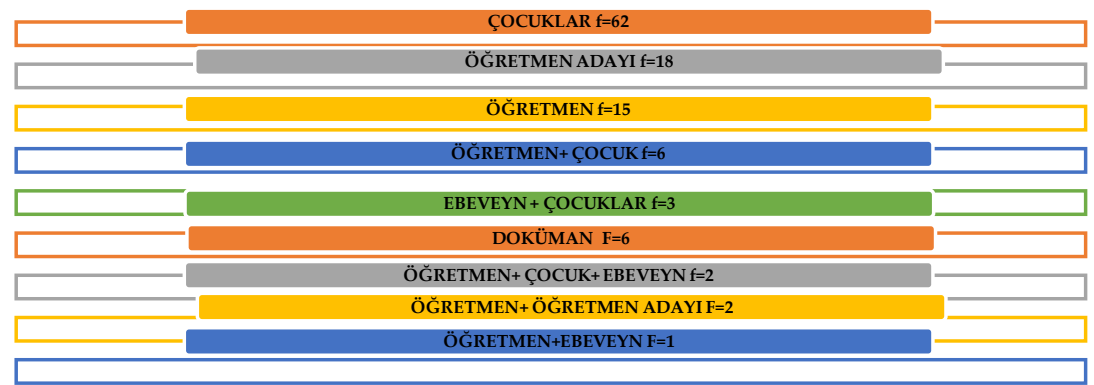

Şekil 7. Okul öncesi dönemde matematik eğitimi ile ilgili çalışmalarnn içerdiği örneklem/çalışma grubuna göre dağılımı

Şekil 7'de incelenen araştırmaların örneklem/çalışma grubunun çoğunlukla "çocuklar" ( $\mathrm{f}=62$ ) olduğu görülmektedir. Bunu sırasıyla "öğretmen adayı" ( $\mathrm{f}=18)$, "öğretmen" ( $\mathrm{f}=15)$; "öğretmen ve çocuk" ( $\mathrm{f}=6)$; "ebeveyn ve ço$\operatorname{cuk}$ " $(\mathrm{f}=3)$; “Doküman” ( $\mathrm{f}=6)$; “Ebeveyn, çocuk ve öğretmen” ( $\mathrm{f}=2)$; Öğretmen ve öğretmen adayı" ( $f=2)$; "Öğretmen ve ebeveyn" ( $(\mathrm{f}=1)$ şeklindeki örneklem/çalışma grupları izlemektedir. Çalışmaların içerdiği örnekleme yöntemlerine göre dağılımı Şekil 8' de verilmiştir.

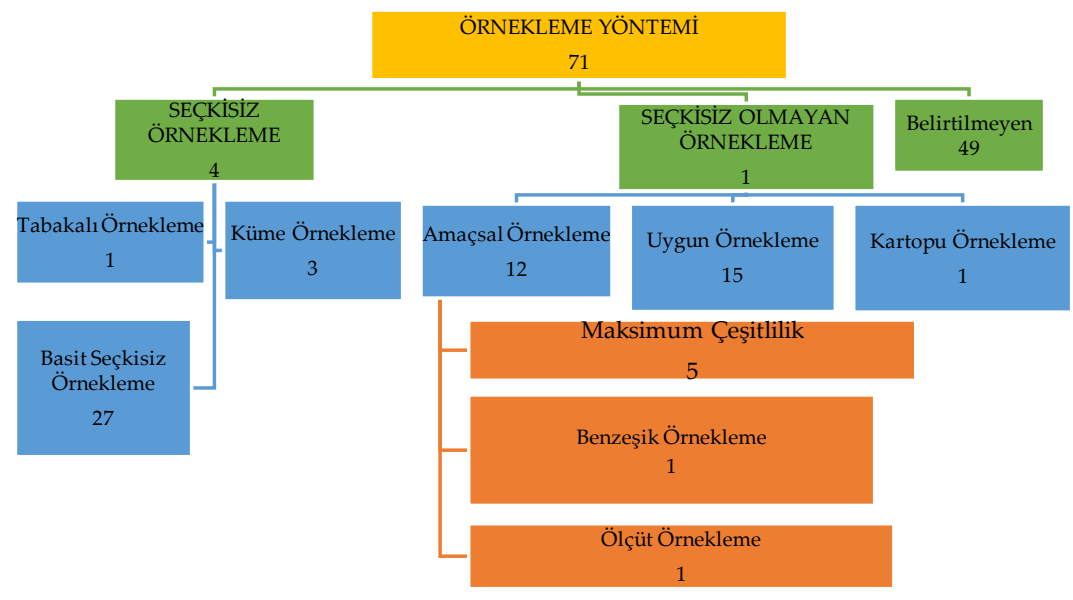

Şekil 8. Okul öncesi dönemde matematik eğitimi ile ilgili çalışmalarnn içerdiği örnekleme yöntemlerine göre dağılımı 
Şekil 8'de incelenen araştırmalarda toplamda 120 örnekleme yönteminin kullanıldığı ancak bunlardan sadece 71 'inde örnekleme yönteminin açıklandığı, geriye kalan 49'unda örnekleme yöntemine ilişkin herhangi bir açıklama yapılmadığ 1 görülmektedir. Örnekleme yöntemi belirtilenlerden ( $\mathrm{f}=71)$ 35'inde seçkisiz örnekleme yöntemi, 36'sında seçkisiz olmayan örnekleme yöntemi kullanıldığı belirlenmiştir. Araştırmada kullanılan seçkisiz örnekleme yöntemleri sırasıyla basit seçkisiz örnekleme ( $f=27)$, küme örnekleme $(\mathrm{f}=3)$, tabakalı örnekleme ( $\mathrm{f}=1)$ şeklindedir. Ayrıca örnekleme yöntemi "seçkisiz örnekleme" olarak ifade edilen türü belirtilmeyen $(\mathrm{f}=4)$ çalışmalar olduğu da görülmüş̧ür. Çalışmaların içerdiği veri analiz tekniklerine göre dağılımı Şekil 9'da verilmiştir.

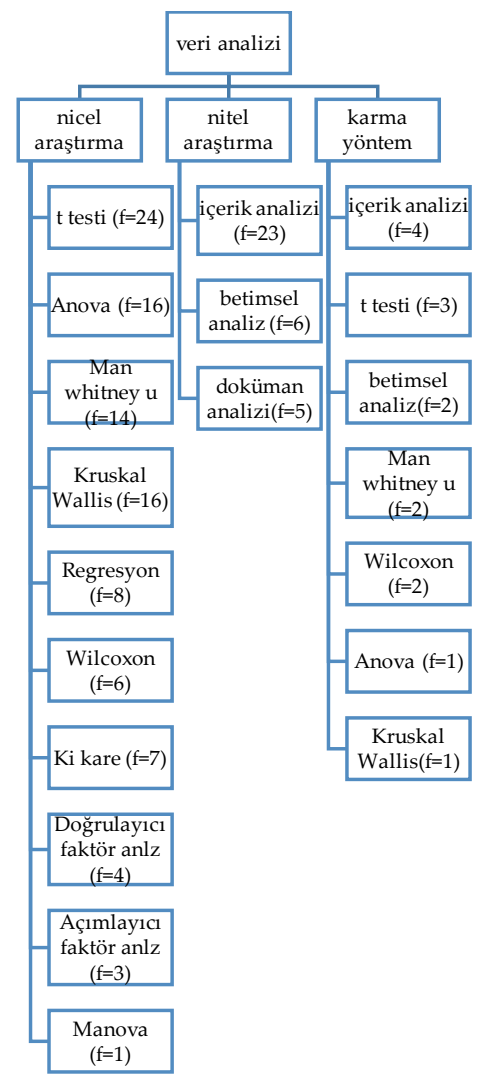

Şekil 9. Okul öncesi dönemde matematik eğitimi ile ilgili çalışmalarm içerdiği veri analiz tekniklerine göre dağılımı 
Şekil 9'da çalışmaya dahil edilen araştırmalarda kullanılan veri toplama araçları çerçevesinde yapılan istatistiksel analizlere yer verilmiştir. Bir veri toplama aracında birden fazla istatistiksel analiz yapılabildiğinden istatistiksel analiz sayısı toplam araştırma sayısından fazladır. Şekilde görüldüğü gibi araştırmalarda farklı veri analiz yöntemlerinin kullanıldığı görülmektedir. Bununla birlikte sayıca fazla olan nicel araştırmalarda kullanılan veri analiz tekniklerinin temel istatistiksel testler olduğu söylenebilir. Vardamsal istatistik yöntemlerinden regresyon ( $\mathrm{f}=8)$, t-testi $(\mathrm{f}=24)$, ANOVA ( $\mathrm{f}=16)$, Manova $(\mathrm{f}=1)$ ve non-parametrik test $(\mathrm{f}=43)$ karşılıkları kullanılmıştır. Bunun yanı sıra nitel araştırmalarda çoğunlukla içerik analizinin yapıldığı $(\mathrm{f}=23)$ bunun yanında betimsel analiz ve doküman analizi tekniklerinin de kullanıldığı görülmüştür.

\section{Sonuç ve Tartışma}

Bu çalışmada, Türkiye'de okul öncesi dönemde matematik eğitimi alanında Haziran 2012-Mart 2019 tarihleri arasında yayımlanan bilimsel makaleler ve lisansüstü tezler çeşitli açılardan incelenmiştir. Bu incelemeler yapılırken çalışmaya dahil edilen araştırmaların künyesi konusu, deseni, veri toplama araçları, örnekleme yöntemi, örneklem/çalışma grubu ve veri analiz türü incelenmiş ve toplamda dokuz araştırma sorusuna cevap aranmıştır.

Çalışmada incelenen araştırmalardan elde edilen sonuçlara bakıldığında, büyük bir çoğunluğunun araştırma makalesi olduğu ve tez çalışma sayısının neredeyse üçte bir oranında daha az olduğu; yayınlandıkları yıllar dikkate alındığında, 2012-2017 yılları arasında matematik eğitimine ilişkin çalışmaların artış gösterdiği ancak, 2018-2019 yıllarında bu artışın görülmediği ve makalelerinin yarından fazlasının uluslararası indekslerde taranan dergilerde yayımlandığı, bu dergilerin büyük bir kısmının eğitim fakülteleri veya eğitim bilimleri enstitülerinin dergileri olduğu buna karşın SSCI kapsamında uluslararası indekslerde taranan nitelikli çalışma sayısının oldukça az olduğu belirlenmiştir. Okul öncesi eğitim alanı 1998 yılında kadar çeşitli fakültelerin veya yüksekokulların bünyesinde farklı isimlerle yapılanmış bir halde iken 1998 yılında zorunlu eğitimin 8 yıla çıkarılması nedeniyle YÖK'ün eğitim fakültelerinin yeniden yapılandırılması çalışmaları kapsamında temel eğitimin bir parçası olarak eğitim fakültesi çatısı altına girmiştir. Bu bağlamda oldukça yeni bir alan olduğu ve okul öncesi eğitime ilişkin çalışmaların bu tarihten 
sonra daha kapsamlı ve çeşitli hale geldiği görülmektedir (Dağlığlu ve Genç, 2018; Deretarla Gül, 2018). Bu duruma paralel olarak yapılan araştırmada da görüldüğü gibi okul öncesi dönemde matematik eğitimine ilişkin çalışmaların sayısında düzenli bir artış olduğu görülmektedir. Ancak, 2018-2019 yıllarında çalışmaların sayısında azalma olması, seçilen çalışmaların 2019 mart ayına kadar yayımlanan makale ve tezlerle sinırlı olmasından, dergilerden yılda bir veya iki kez yayımlananların yayım tarihinde bazen gecikmeler yaşanmasından, bilimsel dergilerin standartlarının artması ve dolayısıyla da yayın yapmanın zorlaşmasından ya da yeni tezlerin YÖK'ün tez kataloğuna girmesinin oldukça uzun sürmesinden kaynaklandığı düşünülmektedir.

Bununla birlikte yapılan araştırmalarda ele alınan konular incelendiğinde araştırmaların büyük bir kısmında çocukların ardından sırasıyla öğretmen adayı, öğretmen, aile ve çeşitli dokümanlarla ilgili konuların tercih edildiği belirlenirken konular kategorize edildiğinde çocuklarla ilgili konuların daha çok matematik eğitimi standartlarını, öğretmen ve öğretmen adaylarına ilişkin hususlarda ise öğretmenlerin genel yeterliklerini içerdiği ortaya çıkmıştır. Diğer yandan çocuklarla birlikte öğretmenlerinin veya ebeveynlerinin çalışma grubuna dahil edildiği çalışmaların da olduğu ancak, sadece çocuklar veya öğretmenler ile yürütülen çalışmalara kıyasla daha az sayıda olduğu söylenebilir.

NCTM (2000; 2006) matematik eğitim programının ve öğretim uygulamalarının hem matematik içerik alanlarını hem de çocukların gelişim özelliklerini göz önünde bulundurarak sağlam bir temel üzerinde yapılandırılması gerektiğine vurgu yapmış ve temel olarak matematik becerileri ve süreçlerinin ezberlenerek değil materyal, akran, yetişkin ve çevre ile etkileşim halinde anlayarak öğrenilmesi gerektiği yaklaşımını benimsemiştir. Bu bağlamda matematik eğitiminde çocukların bu alandaki gelişimlerinin takibi kadar çocuğun çevresindeki kişiler ve bu kişilerin bilgi ve bilinç düzeyleri ile birlikte onlara sağladıkları öğrenme ortamı gibi boyutların da dikkate alındığı araştırmalara daha çok yer verilmesi gerektiği ortaya çıkmaktadır. Bu konuda Türkiye'de yapılan araştırmalar incelendiğinde, Ulutaş ve Ubuz (2008) yaptıkları çalışmada matematik eğitimi ile ilgili araştırmaların çoğunluğunun konusunun çocukların ve öğretmen adayları ile ilgili olduğunu belirlerken Tatar ve Tatar (2006) inceledikleri çalışmaların konusunun daha çok lisans öğrencileri ile ilgili olduğunu vurgulamıştır. Bu bulgular araştırmada elde edilen sonuçlarla paralellik göstermektedir. 
Öğretmen ve öğretmen adaylarına ilişkin konularda Türkiye, "Avrupa Genel Yeterlikler Çerçevesi" ne uygun olarak ulusal yeterliklerini belirlemiş MEB Öğretmenlik Mesleği Genel Yeterlikleri'ni güncellemeye ihtiyaç duymuştur. Bu hedef doğrultusunda 2017 yılında MEB öğretmenlerin genel yeterliklerini üç başlık altında toplamıştır (MEB, 2017). Bunlardan ilki, öğretmenin görev yaptığı alanda sahip olması gereken temel bilgi ve beceriyi içeren "mesleki bilgi"dir. İkinci yeterlik alanı olan "mesleki beceri", mesleki bilgiye sahip olan öğretmenlerin bu bilgilerini kullanarak eğitim sürecini çocukların yaş ve gelişim özelliklerine uygun olarak planlamaları, birbirinden farklı özelliklere sahip çocukların gelişimsel ve eğitimsel ihtiyaçlarını karşılayan eğitim ortamı oluşturmaları, yönetmeleri ve sonunda yaptıkları eğitimin verimliliğini çeşitli açılardan değerlendirmelerini içermektedir (Dağloğlu ve Genç, 2018). Son yeterlik alanı "tutum ve değerler" ise, mesleki bilgi ve beceriye sahip öğretmenlerin sahip oldukları bu bilgi ve becerileri profesyonel yaklaşımları ile harmanlayarak hitap ettikleri yaş grubuna kazandırılması öngörülen milli, manevi ve evrensel değerleri kazandırmalarını içerir. Yapılan araştırma sonucunda öğretmen ve öğretmen adaylarını konu alan çalışmalarda daha çok mesleki bilgi ve beceriye ilişkin unsurların ön plana çıktığı, tutum ve değerlere ilişkin özelliklerin göz ardı edildiği bunun yerine daha çok öğretmen ve öğretmen adaylarının alg1/görüşlerini içeren çalışmalara yer verildiği belirlenmiştir.

Literatürde ebeveynlerin, çocukların matematik gelişimlerini desteklemede önemli role sahip olduğu vurgulanmaktadır. Ebeveynler çocuklarının matematik gelişimlerini desteklemek için zengin çevre imkânı sunabilmekte, çocuğun devam ettiği eğitim programını destekleyebilmekte evde ya da herhangi bir yerde belirli aktiviteler uygulayabilmektedirler (Ginsburg, Duch, Ertle ve Noble, 2012). Ayrıca ailelerin eğitim düzeyinin, ev ortamında kullandığı matematik dilinin, matematiğe karşı tutumlarının ve sahip oldukları matematik kavram bilgisinin çocuklarının matematik becerilerinin gelişiminde önemli bir role sahip olduğu düşünülmektedir (Güven ve Gök Çolak, 2019; Orçan Kaçan, Yazıcı ve Kandır, 2018). Araştırma sonucunda okul öncesi dönemdeki çocukların matematik gelişimlerini desteklemede ailenin rolünü inceleyen sınırlı sayıda çalışmaya rastlanılmıştır ve bu çalışmaların çoğunlukla aile katılımına ilişkin olduğu tespit edilmiştir. 
Tüm eğitim kademelerinde olduğu gibi okul öncesi eğitimin etkililiği ve kalitesi uygulanan eğitim programlarının niteliğine bağlıdır (Baki ve Hacısalihoğlu Karadeniz, 2013). Hem okul öncesi eğitimi programının hem de okul öncesi öğretmenliği lisans eğitim programının matematik eğitimi açısından ele alınmasının önemli olduğu düşünülmektedir. Bunun yanı sıra bu yaş grubu çocuklar için kullanılan hikâye kitapları, materyaller ve yardımcı kaynakların çocukların matematik kavram ve becerilerini somutlaştırmasına ve daha anlamlı hale getirmesine yardımcı olmaktadır (İnal Kızıltepe, Öztürk Samur ve Tekin, 2018; Sertsöz ve Doğan Temur, 2017). Araştırma sonucunda okul öncesi dönemde matematik eğitimine ilişkin doküman incelemesi çalışmalarının sınırlı sayıda olduğu ve bu çalışmalarda doküman olarak okul öncesi eğitim lisans programının, okul öncesi dönem çocukları için hazırlanmış programın ve hikâye kitaplarının incelendiği belirlenmiştir. Bu bağlamda matematik eğitimi açısından hazırlanan gerek çocuklara gerekse öğretmen adaylarına yönelik programların, materyal ve yardımcı kaynakların incelenmesi çocukların matematik alanında potansiyellerinin ortaya konup geliştirilmesi açısından oldukça önem taşımaktadır.

Çalışmada nicel araştırma metodunun daha çok kullanıldığı, bunu nitel yöntemin izlediği ve karma araştırmaların oldukça az sayıda olduğu gözlenmiştir. Hart, Smith, Swars ve Smith (2009) tarafından yapılan araştırmada, 1995 ve 2005 yılları arasında matematik eğitimine ilişkin yapılan araştırmalar kullanılan yöntemlere göre sınıflandırılmıştır. Çalışma sonucunda incelenen makalelerin \%50'sinde nitel, \%21'inde nicel ve \%29'unda karma yöntemlerin kullanıldığı belirlenmiştir. Lubiensky ve Bowen (2000), tarafından yapılan bir başka çalışmada, 1982 ve 1998 yılları arasında ERIC veri tabanından ulaşılabilen 3011 matematik eğitimi araştırması incelenmiş ve en fazla ilköğretim kademesinde araştırma yapılırken en az okul öncesi ve yetişkin eğitiminde bilimsel araştırma yapıldığı sonucuna ulaşılmıştır. Dünyada yapılan araştırmalara paralel olarak Türkiye'de de, Ulutaş ve Ubuz'un (2008) araştırması sonucunda 2000-2006 yılları arasında yapılan çalışmalarda kullanılan yöntemler incelenmiş ve nicel araştırmaların dağılımının en temelde kullanılan yöntem olduğu belirlenmiştir. Göktaş vd. (2012) bu durumun, araştırmacıların yürüttükleri çalışma sonuçlarını genellemeye ilişkin kaygılarının olması, uygulama süresinin kısa olması, daha hızlı ve kolay bir şekilde istenen büyüklükte örnekleme ulaşılması, diğer yandan zaman ve maliyet avantajları gibi nedenlerden kaynaklanabileceği şeklinde yorumlamış ve nitel araştırma 
ve karma yöntemli araştırmaların sayısının sınırlı olduğunu belirtmişlerdir. Yılmaz vd. (2010), alanda nitel araştırmaların sayısının az olmasının sebebinin, Türkiye'deki eğitim dergilerinde pozitivist paradigmanın baskınlığı nedeniyle, nicel çalışmaların nitel verilerden daha fazla yayınlanmasından kaynaklanabileceğini belirtmiştir. Nicel araştırmalarda elde edilen sayısal veriler, belli bir boyut içerisinde çeşitli grupların benzerliklerini, oranlarını veya farklılıklarını ortaya koyar. Nitel araştırmalarda ise daha çok araştırmacının araştırdığı olguyu manipüle etmeden olguların anlaşılmaya çalışıldığı bir araştırma sürecidir (Patton, 2014). Dolayısıyla daha derinlemesine ve çoklu şekillerde yapılabilmesi nitel araştırma verilerinin nitelik açısından değerini ortaya koymaktadır. Bu bağlamda matematik eğitimi alanında bu şekilde derinlemesine yapılan araştırmalara ihtiyaç duyulduğu söylenebilir.

Karma yöntem araştırmalarında ise, araştırmacının anlama ve doğrulamanın genişliği ve derinliğini ortaya koymak amaciyla nitel ve nicel araştırma yaklaşımlarının boyutlarını birleştirdikleri bir araştırma türüdür (Creswell, 2017, s.15). Dolayısıyla nitel araştırma ve karma yöntemli araştırmalarda daha ayrıntılı bulgular elde edilebilmektedir. Ancak incelenen araştırmalar göstermektedir ki Türkiye'de bu konuda yapılan araştırmalarda karma yöntem çok fazla tercih edilmemektedir.

Nicel araştırma metodunun kullanıldığı çalışmalara bakıldığında tarama deseninin yoğunlukta olduğu görülmektedir. Gökmen vd.'nin (2017) yaptıkları çalışmada da benzer sonuçlara ulaşılmış, incelenen araştırmaların çoğunluğunun tarama modeli ile yürütüldüğü gözlenmiştir. Tarama deseninin yanı sıra nicel araştırma yöntemleri içerisinde deneysel karşılaştırma, deneysel araştırma tasarım geliştirme araştırması ve meta-analiz desenlerinin de bulunduğu bilinmektedir (Büyüköztürk, Kılıç Çakmak, Akgün, Karadeniz ve Demirel, 2018; Yıldırım ve Şimşek 2013). Deneysel araştırmalarda çocuklara uygulanan farklı eğitim programlarının etkisi araştırılabilmektedir. Dolayısıyla çocuklar ile yapılan etki araştırmalarının sınırlı sayıda olması, matematik eğitiminde deneysel araştırmalara daha çok ihtiyaç olduğunun bir göstergesidir. Bunun yanı sıra nicel araştırma yöntemlerinden biri olan meta analiz çalışmaları, belirli bir amaca veya konuya yönelik yapılan çalışmaları birlikte ele alıp inceleyerek bu çalışmaların sonuçlarından bir senteze ulaşılmasını sağlar (Büyüköztürk vd., 2018). Alanda yapılan çalısmalara genel bir bakış kazandırmayı amaçlayan bu çalışmaların değerli olduğu söylenebilir. Dolayısıyla incelenen çalışmalar içerisinde meta-analiz çalışmalarının olmaması 
nedeniyle bu konuda ileride yapılacak çalışmalara 1şık tutması bağlamında alandaki eksikliği ortaya koyduğu söylenebilir. Ayrıca ölçek geliştirme çalışmalarının matematik eğitimi alanında oldukça önemli bir yeri vardır. Bu çalışmalar, çocukların içinde yaşadıkları kültüre uygun olan ölçeklerin geliştirilmesini sağlamaktadır. Okul öncesinde matematik eğitimi alanında gerçekleştirilen çalışmalar içerisinde ölçek geliştirme veya uyarlama çalışmalarının oldukça sınırlı sayıda olduğu görülmüştür. Okul öncesi dönemde matematik eğitimi Türkiye'de henüz gelişmekte olan bir alan olduğu için gerek çocuk, öğretmen, öğretmen adayı, gerekse aile ve ortam ile ilgili geliştirilen veya uyarlanan ölçekler var olan durumun ortaya konması açısından oldukça değerlidir.

Nitel araştırmalar içerisinde, tarihi araştırma, eylem araştırması, kuram oluşturma, etnografik araştırma, fenomenoloji, anlatı araştırması gibi birçok desen olduğu bilinmektedir (Merriam, 2015; Savin-Baden ve Major, 2013). Oysa matematik eğitimi alanında yapılan çalışmalarda, çocukların veya öğretmenlerin görüşlerinin ele alındığı araştırmaların ağırlıkta olduğu görülmektedir. Araştırmacının doğrudan katılımcı olarak belirli bir durumun koşullarını değiştirmeye yönelik bilgi elde etmeyi amaçlayan eylem araştırmaları veya belirli bir grubun üyeleriyle ilişki kurmak, kültürel yapılarını veya bu yapıları oluşturan davranış ve deneyimleri açıklamayı amaçlayan etnografik araştırmalar alanda değerli görülen araştırmalardır (Büyüköztürk vd., 2018). Dolayısıyla alandaki en büyük gereksinim, farklı araştırma yöntemleri kullanılarak matematik eğitimine ilişkin mümkün olduğunca farklı kaynaklardan derin ve nitelikli bulgular elde ederek bakış açısının genişletilmesidir.

Yapılan araştırmada veri toplama aracı olarak sıklıkla anket ve çocukların matematik gelişimini belirlemeye yönelik ölçeklerin kullanıldı̆̆ı görülmüştür. Ulutaş ve Ubuz (2008) tarafından yapılan çalışma da bu bulguyu desteklemektedir. Çalışmalarda matematik kavramlarından en çok sayı kavramı üzerinde durulduğu görülmekle birlikte işlem ve geometrik şekilleri tanıma gibi temel kavramlara da yönelik ölçeklerin kullanıldığı belirlenmiştir. İncelenen araştırmaların temel aldığı konular arasında matematik süreç becerilerini ölçmeye yönelik değerlendirme araçlarının da oldukça sınırlı olduğu söylenebilir. NCTM'nin (2000), matematik eğitimine ilişkin olarak matematik içerik ve süreçlerinin birlikte ele alındığ 1 bir yaklaşımın çocukların matematiksel düşüncelerini ve matematik başarılarını geliştirmede son derece etkili 
olduğunu ifade ettiği dikkate alındığında bu konuda kullanılan ölçme araçlarında da bu yönde bir yaklaşımın olması gerektiği düşünülmektedir. Öğretmenler ve öğretmen adayları ile yapılan çalışmalarda tutum, inanç ölçeklerinin veya öz yeterlik anketlerinin ve görüşme formlarının sıklıkla kullanıldığı belirlenmiştir.

Araştırmalarda yer alan örneklem grupları incelendiğinde çoğunlukla grupların çocuklardan oluştuğu belirlenmiştir. Ancak bu bağlamda örneklem gruplarının çocuklarla birlikte aile, öğretmen, ortam vb. değişkenleri birlikte ele alan bir yaklaşım içerisinde olması çocukların gelişimleri ve onların bu gelişim süreçlerini olumlu ve olumsuz yönde etkileyen unsurları belirlemek açısından çok daha yararlı olacağı söylenebilir. Bununla birlikte çalışmaların kayda değer bir kısmında örnekleme yönteminin belirtilmediği ortaya çıkmıştır. Nicel araştırma yöntemi ile yürütülen çalışmalarda örnekleme yönteminin daha fazla belirtildiği görülürken nitel araştırma yöntemi ile yürütülen çalışmalarda genellikle amaçlı örnekleme yönteminin kullanıldığı bulunmuştur. Büyüköztürk ve Kutlu (2006) tarafından yürütülen araştırmaya göre, incelenen araştırmalarda karşılaştıkları en sık yöntem problemlerinden birinin örneklem ve örnekleme yönteminin tanımlanmasındaki ihmal olduğu belirtilmektedir. Bunun yanı sıra örneklem yönteminin belirtilmemesinde, Göktaş ve diğerleri (2012), Fraenkel ve Wallen (2003) ile Şimşek ve diğerlerinin (2009) çalışmalarında belirttikleri gibi araştırmacıların yöntem konusundaki bilgilerinin sınırlı olabileceği durumu gösterilebilmektedir. Oysa araştırmanın yöntem kısmında örnekleme ilişkin tüm bilgilerin detaylı bir şekilde yazılması araştırmanın iç geçerliliğine katkı sağlayan önemli bir unsurdur.

Yapılan çalışmalarda kullanılan veri analiz yöntemleri incelendiğinde ise daha çok temel istatistiksel analizlerin tercih edildiği söylenebilir. Bağcı ve İvrendi (2016), çalışmasında daha çok nicel araştırma yöntemini tercih eden araştırmacıların çoğunlukla verilerin analizi kısmında betimsel istatistiklere yer verdiklerini belirtmiştir. Tarama çalışmalarının diğer çalışmalara oranla daha fazla yapıldığı dikkate alındığında t-testi ve ANOVA testlerinin yapılması karşılaştırmalı analizlerin fazla sayıda yapıldığının göstergesidir. Bu analizlerin yapılmasının sebebi değişkenler arasında incelenen özelliklerin daha kolay açıklanabilecek şekilde kurgulanması veya nispeten daha kolay yorumlanabilmesidir (Selçuk vd., 2014). Bunun yanı sıra araştırmalarda kullanılan veri analiz teknikleri ve neden kullanıldıklarıyla ilgili bilgilerin araş- 
tırma raporuna detaylı bir şekilde yazılması gerekmektedir (Erkuş, 2004). Nihayetinde kullanılan veri analiz teknikleri araştırmanın geçerliliğine katkı sağlamaktadır.

Sonuç olarak 2012-2019 yılları arasında okul öncesi dönemde matematik eğitimi ile ilgili yapılan çalışmaların büyük çoğunluğunun araştırma makalesi olduğu ve tez sayısının neredeyse üçte bir oranında daha az olduğu; 20122017 yılları arasında matematik eğitimine ilişkin çalışmalarda düzenli bir artış olduğu; incelenen makalelerinin yarıdan fazlasının uluslararası indekslerde taranan dergilerde yayımlandığı buna karşın SSCI'da taranan çalışma sayısının oldukça az olduğu; araştırmaların büyük bir kısmında çocukların ardından sırasıyla öğretmen adayı, öğretmen, aile ve çeşitli dokümanlarla ilgili konuların tercih edildiği; çalışmalarda nicel araştırma metodunun daha çok kullanıldığı, bunu nitel ve karma yöntemin kullanıldığı çalışmaların izlediği; veri toplama aracı olarak sıklıkla anket ve çocukların matematik gelişimini belirlemeye yönelik ölçeklerin kullanıldığı ve buna paralel olarak örneklem/çalışma gruplarının büyük bir kısmının çocuklardan oluştuğu; çalışmaların kayda değer bir kısmında örnekleme yönteminin belirtilmediği ve bu duruma nicel araştırma yöntemi kullanılan çalışmalarda daha fazla rastlandığı; nitel araştırma yöntemi kullanılan çalışmalarda genellikle amaçlı örnekleme yönteminin tercih edildiği; veri analiz yöntemleri incelendiğinde ise her üç araştırma yönteminin kullanıldığı araştırmalar için daha çok temel istatistiksel analizlerin yapıldığı belirlenmiştir.

Araştırmanın sonuçları doğrultusunda bundan sonraki süreçte, matematik eğitimi alanında yapılan araştırmaların düzenli aralıklarla (örneğin beş yılda bir gibi) incelenmesi ve bu incelemelerde çalışmaların niteliksel özelliklerinin dikkate alınması önerilebilir. Söz konusu alanla ile ilgili hazırlanan makalelerin yayın kapsamı matematik eğitimi ya da matematik ve fen eğitimi olan ulusal ve/veya uluslararası dergilerde yayımlanması tercih edilebilir. Makalelerin yayımlandığı dergilerin tarandığı indeksler dikkate alını kapsamlı çalışmalar planlanarak daha nitelikli dergilerde (SSCI) yayımlanması konusunda araştırmacıları özendirici birtakım teşvikler sunulabilir. Okul öncesi eğitim yeni gelişen bir alan olması nedeniyle gerek çocuk, gerekse öğretmen, öğretmen adayı ve aileler ile ilgili kültüre özgü olarak geliştirilecek ölçeklere ihtiyaç duyulmaktadır. Bu bağlamda daha sonraki yapılan çalışmalarda matematik eğitimine iliş̧kin geliştirilen ölçeklerin ele alındığı çalışmalar ayrıntılı olarak incelenebilir. Okul öncesi dönemde matematik eğitimi ile ilgili 
araştırmalar incelendiğinde özellikle nicel araştırma yöntemlerinin daha çok tercih edildiği görülmektedir. İleriki araştırmalarda nitel ve karma yöntemin kullanıldığı çalışmalar yapılarak incelenen konuya ilişkin daha nitelikli sonuçlar elde edilmesi sağlanabilir. İncelenen araştırmalarda daha çok temel istatistiksel analizler kullanıldığı belirlenmiştir. Planlanan araştırmalarda ileri istatistikler kullanılarak daha nitelikli bulgulara ulaşılması sağlanabilir. İncelenen araştırmaların büyük bir kısmının örneklem grubunu çocukların oluşturduğu görülmektedir. Daha sonraki çalışmalarda sadece çocuk değil çocuğun çevresindeki ailesi, öğretmeleri, eğitim ortamı, ev ortamı gibi unsurların birlikte ve ayrı ayrı ele alındığı farklı araştırma yöntemlerinin kullanıldığı çalışmalar planlanabilir. Okul öncesi eğitime yönelik dokümanların (okul öncesi eğitim programı, lisans programı, hikaye kitapları, kaynak kitaplar, ders kitapları vb.) farklı değişkenlere dikkate alınarak incelenmesi çocukların potansiyellerini ortaya koyup geliştirmeleri sağlamak açısından yararlı olacaktir. 


\title{
EXTENDED ABSTRACT
}

\section{A Content Analysis on Studies Conducted on Math Education in Preschool in Turkey}

$*$

\author{
Rukiyye Yıldız Altan - Hilal Genç Çopur- H. Elif Dağlıŏlu \\ Gazi University- Kırşehir Ahi Evran University
}

Early mathematics education contributes to children's learning in the short and long term (Björklund, Magnusson ve Palmér, 2018; Newton ve Alexander, 2013S9. Some experimental studies with children revealed that mathematics studies related to the acquisition of mathematical concepts and skills create differences in children's mathematics competence when they start primary school, and these differences persist throughout their school life and even later (Magnuson, Duncan, Lee ve Metzger, 2016; National Research Coun-cil, 2009; Nguyen vd., 2016). This situation reveals that preschool mathematics education is important regarding their future acquisition of successful mathematical thinking skills and readiness towards primary school. Recent developments in the fields of science and mathematics have increased the interests of countries in these fields. An investigation of recent studies on mathematics education offers researchers, educators, and teachers the opportunity to have scientific discussion and inquiry in this field. Since it is important to determine the trends by investigating the studies at regular intervals in terms of shedding light on researchers who works in the relevant field (Cohen, Manion ve Morrison, 2007). This study differs from other studies in that it includes both research articles and graduate theses on mathematics education in preschool conducted in the last seven years. Besides, the papers included in this study were investigated according to a systematic checklist. Therefore, it is considered that this study will contribute to the field by providing more up-to-date and systematic information and guide research activities to be conducted afterward.

The purpose of the current study is to investigate the graduate theses and research articles conducted in 2012-2019 on mathematics education in the preschool period in Turkey. This study was designed as a descriptive, qualitative study in which a synthesis of studies on preschool period mathematics 
education in Turkey was conducted. The studies included in the present study were selected by criterion sampling which is one of the purposive sampling methods. The criteria were determined as being published in the last seven years in the mathematics education in pre-school, at least one of the researchers' being based in Turkey, for graduate theses, being conducted in Turkey between June 2012 and March 2019 on mathematics education in preschool, and for the research articles being published in journals indexed in national and international indexes in Turkish or English language. As a result of the literature review conducted per the determined criteria, a total of 131 studies on mathematics education in the pre-school period were collected. While 47 of these studies were graduate theses, 84 were research articles. Since the 16 articles were based on graduate theses ( 11 of them were used the data from master's theses and 5 of them from $\mathrm{PhD}$ theses), those theses were not included in the study. Therefore, a total of 115 studies were examined within the scope of the current study. To examine the studies included in the present study, the "Research Examination Checklist" developed by the researchers based on the "Article Classification Form" created by Çiltaş, Güler, and Sözbilir (2012) was used. The data were analyzed with the inductive content analysis approach. The studies examined were coded by the researchers separately and the agreement between the coders was calculated. The reliability of the data analysis was tested using Miles and Huberman's (1994) formula. Accordingly, the agreement percentage between coders was found as .95 .

The findings of the study revealed that the majority of the studies were research articles and the ratio of theses was almost one third less; regarding their publication years, studies on mathematics education increased between 2012 and 2017, but this increase was not seen in 2018-2019 and more than half of the articles were published in journals indexed by international institutions, and most of these journals were journals of education faculties or educational sciences institutes. It was found out that the number of quality studies indexed in international indexes within the scope of SSCI was quite low. In most of the studies, the research subjects were either the children or the preservice teachers, teachers, parents, and various documents. It was determined that the quantitative research method was used more frequently in studies, this was followed by studies that adopted a qualitative and mixed-method 
design. Questionnaires and scales were frequently used to determine the mathematics development of children as data collection tools, and in parallel to this, a large part of the sample/study group consists of children. In studies using qualitative research methods, the purposive sampling method is usually preferred. On the other hand, the data analysis methods were found to as using basic statistical analysis for studies in which all three research methods were used. According to the results of the study, it may be suggested that the studies in the field of mathematics education should be examined regularly (such as every five years) and the quality of the studies should be considered in these examinations. Since preschool education is a developing field, there is a need for culture-specific scales for children, teachers, preservice teachers, and parents. Therefore, studies on the scales developed for mathematics education can be examined in detail in future studies. On the other hand, it was revealed that the samples of most of the studies examined consist of children. In future studies, studies using different research methods may be planned in which factors such as not only the child but also the child's parents, teachers, educational environment, home environment may be handled together and separately.

\section{Kaynakça / References}

Bağcl, B. ve İvrendi, A. (2016). Türkiye' de okul öncesi dönem matematik becerileri ve eğitimi araştırmaları: sentez çalışması. Necatibey Ĕ̆itim Fakültesi Elektronik Fen ve Matematik Eğitimi Dergisi, 10(2), 395- 425.

Baki, A., Güven, B., Karataş, İ., Akkan, Y. ve Çakıroğlu, Ü. (2011). Trends in Turkish mathematics education research: From 1998 to 2007. Hacettepe Üniversitesi Eğitim Fakültesi Dergisi, 40, 57-68.

Baki, A. ve Hacısalihoğlu-Karadeniz, M. (2013). Okul öncesi eğitim programınn matematik uygulama sürecinden yansimalar. Kastamonu Ĕ̆itim Dergisi, 21(2), 619-636.

Björklund, C., Magnusson, M. ve Palmér, H. (2018) Teachers' involvement in children's mathematizing - beyond dichotomization between play and teaching, European Early Childhood Education Research Journal, 26(4), 469-480. DOI: 10.1080/1350293X.2018.1487162.

Büyüköztürk, Ş., Kıllı̧ Çakmak, E., Akgün, Ö. A., Karadeniz, Ş. ve Demirel, F. (2018). Bilimsel araştırma yöntemleri. Ankara: Pegem. 
Büyüköztürk, Ş., ve Kutlu, Ö. (2006). Sosyal bilim araştırmalarında yöntem sorunu. Sosyal Bilimlerde Süreli Yaymallk-2006-I. Ulusal Kurultay Bildirileri içinde(s. 113122). Ankara: TÜBITAK.

Claesens, A., ve Engel, M. (2013). How important is where you start? Early mathematics knowledge and later school success. Teachers College Record, 115(6), 1-29.

Creswell, J. W. (2017). Karma yöntem araştrmalarna giriş. M. Sözbilir (Çev.) Ankara: Pegem.

Cohen, L., Manion, L., ve Morrison, K. (2007). Research methods in education (6th ed.). New York: Routledge.

Çiltaş, A., Gürsel, G. ve Sözbilir, M. (2012). Türkiye'de matematik eğitimi araştırmaları: Bir içerik analizi çalışması. Kuram ve Uygulamada Eğitim Bilimleri, 12(1), 565-580.

Dağlıŏglu, H.E., Dağll, H. ve Kılıç, N.M. (2014). Okul öncesi eğitimi öğretmen adaylarının matematik eğitimi dersine karşı tutumlarının çeşitli değişkenler açısından incelenmesi. International Conference On Educational Research And Social Sciences Proceedings Book, 293-304, Ankara: Pegem Akademi.

Dağlıoğlu, H. E. ve Genç, H. (2018). Öğretmen yetiştirme ve okul öncesi öğretmenin özellikleri. G. Haktanır (Ed.). Erken çocukluk eğitimine giriş içinde (s. 175-222). Ankara: Anı.

Deretarla Gül, E. (2018). Türkiye'deki okul öncesi eğitim. G. Haktanır (Ed.). Erken çocukluk eğitimine giriş içinde (s. 111-174). Ankara: Anı.

ÜAK. (2019). Doçentlik başvuru şartları. http://www.uak.gov.tr/temelalan/TA Tablo1 2019M 071217.pdf adresinden erişilmiştir.

Erkuş A. (2004). Bazı tip dergilerinin son sayllarındaki makalelerin yöntemsel ve istatistiksel açıdan incelenmesi. Mersin Üniversitesi Trp Fakültesi Dergisi, 5(2), 176-181.

Fraenkel, J. R., ve Wallen, N. E. (2006). How to design and evaluate research in education. New York: McGraw-Hill.

Ginsburg, H. P., Duch, H., Ertle, B., ve Noble, K. G. (2012). How can parents help theirchildren learn math? içinde: B. H. Wasik (Ed.), Handbook of family literacy. UK: Routledge.

Gökmen, Ö.F., Uysal, M., Yaşar, H., Kırksekiz, A., Güvendi, G. M. ve Horzum, M. B. (2017). Türkiye'de 2005-2014 yllları arasinda yayınlanan uzaktan eğitim tezlerindeki yöntemsel eğilimler: Bir içerik analizi. Eğitim ve Bilim, 42(189), 1-25.

Göktaş, Y., Yeşildağ-Hasançebi, F., Varışoğlu, B., Akçay, A., Bayrak, N., Baran, M ve Sözbilir, M. (2012). Türkiye'deki eğitim araştırmalarında eğilimler: Bir içerik analizi. Kuram ve Uygulamada Ë̆itim Bilimleri, 12(1), 443-460. 
Güven, Y. ve Gök Çolak, F. (2019). Erken çocukluk dönemi matematik eğitiminde ailenin ve öğretmenin rolü. G. Uludağ (Ed.), Erken çocukluk döneminde matematik eğitimi. içinde Ankara: Nobel.

Hart, L.C., Smith, S.Z., Swars, S.L., ve Smith, M.E. (2009). An examination of research methods in mathematics education (1995-2005). Journal of Mixed Methods Research, 3(1), 26-41.

İnal Kızıltepe, G., Öztürk Samur, A. ve Tekin, H. (2018). Çocuk kitapları yoluyla matematik becerilerinin kazandırılmasına yönelik yapılmış araştırmaların incelenmesi. Adnan Menderes Üniversitesi, Sosyal Bilimler Enstitüsü Dergisi, 5(1), 106-123.

İnceoğlu, G. (2009). Matematik eğitimi ve matematik öğretimi alanında yapılan tezlerin bir değerlendirmesi. e-Journal of New World Sciences Academy Education Sciences, 4(3), 1046-1052.

Karasar, N. (2005). Bilimsel araştrma yöntemi, Ankara: Nobel.

Kayhan, M., ve Özgün-Koca S.A. (2004). Matematik eğitiminde araştırma konularr: 2000-2002. Hacettepe Üniversitesi Eğitim Fakültesi Dergisi, 26, 72-81.

Lincoln, YS. ve Guba, EG. (1985). Naturalistic inquiry. Newbury Park, CA: Sage.

Lubienski, S.T., ve Bowen, A. (2000). Who's counting? A survey of mathematics education research 1982-1998. Journal for Research in Mathematics Education, 31(5), $626-633$.

Lundetræ, K., Gabrielsen, E., ve Mykletun, R. (2010). Do basic skills predict youth unemployment (16- to 24-year-olds) also when controlled for accomplished uppersecondary school? A cross-country comparison. Journal of Education and Work 23, 233-254.

Magnuson, K., Duncan, G. J., Lee, K. T. H., ve Metzger, M. W. (2016). Early school adjustment and educational attainment. American Educational Research Journal, 53, 1198-1228.

MEB (2017). Öğretmen Yetiştirme ve Geliştirme Genel Müdürlü̈̆̈̈̈̈̈̆gretmenlik mesleği yeterlikleri. Ankara: Milli Eğitim Bakanlığı.

Merriam, S. B. (2015). Nitel araştırma desen ve uygulama için bir rehber. S. Turan (Çev.). Ankara: Nobel.

Miles, M. B. ve Huberman, A. M. (1994). Qualitative data analysis: An expanded sourcebook. California: Sage.

National Council of Teachers of Mathematics (NCTM) (2000). Principles and standards for school mathematics. Reston, VA: NCTM. 
National Council of Teachers of Mathematics (NCTM) (2006). Curriculum focal points for prekindergarten through grade 8 mathematics: A quest for coherence. Reston, VA: Author.

National Research Council (2009). Mathematics in early childhood: Learning paths toward excellence and equity. Washington, DC: National Academy.

Newton, K. J., ve Alexander, P. A. (2013). Early mathematics learning in perspective: Eras and forces of change. In, ed. L. D. English and J. T. Mulligan, Perspectives on reconceptualizing early mathematics learning (s. 5-28). Dordrecht: Springer.

Nguyen, T., Watts, T. W., Duncan, G. J., Clements, D. H., Sarama, J. S., Wolfe, C., ve Spitler, M. E. (2016). Which preschool mathematics competencies are most predictive of fifth grade achievement? Early Childhood Research Quartely, 36, 550560.

OME, (2014). Ontario Ministry of Education doing mathematics with your child, kindergarten to grade 6: A parent guide. Ontario, USA.

Orçan Kaçan, M., Yazici, E. ve Kandır, A. (2017). Ebeveynlerin çocukların matematik eğitimine ilişkin görüşlerinin incelenmesi. Karadeniz Sosyal Bilimler Dergisi, 15, 301-319.

Patton, M. Q. (2002). Qualitative research and evaluation methods (3d Edition). Thousand Oaks, CA: Sage.

Patton, M. Q. (2014). Nitel araştırma yöntemleri, beş yaklaşıma görenitel araştırma ve araştırma deseni [Qualitative research methods, qualitative research and research design according to five approaches]. (M. Bütün ve S. B. Demir, Çev. ed./Trans. Ed.). Ankara: Siyasal.

Sarama, J. ve Clements, D. H. (2009). Early childhood mathematics education research learning trajectories for young children. New York: Routledge.

Savin-Baden, M. ve Major, C.H. (2013). Qualitative research: The essential guide to theory and practice.

Selçuk, Z., Palancı, M., Kandemir, M. ve Dündar, H. (2014). Eğitim ve Bilim dergisinde yayınlanan araştırmaların eğilimleri: İçerik analizi. Eğitim ve Bilim, 39(173), 430453.

Sertsöz, A., ve Temur, Ö. D. (2017). 6 yaş çocuklarına öyküleştirme yöntemi ile verilen matematik eğitiminin çocukların matematik başarılarına etkisinin incelenmesi. Academy Journal of Educational Sciences, 1(1), 1-10.

Şimşek, A., Özdamar, N., Uysal, Ö., Kobak, K., Berk, C., Kılıçer, T. ve Çiğdem, H. (2009). İki binli yıllarda Türkiye'deki eğitim teknolojisi araştırmalarında gözlenen eğilimler. Kuram ve Uygulamada Eğitim Bilimleri Dergisi, 9(2), 941-966. 
Tatar, E. ve Tatar, E. (2008). Fen bilimleri ve matematik eğitimi araştırmalarını analizi II: Anahtar Kelimeler. İnönü Üniversitesi Eŏitim Fakültesi Dergisi, 9(16), 89-103.

Ulutaş, F., ve Ubuz, B. (2008). Matematik eğitiminde araştrmalar ve eğilimler: 2000 ile 2006 yılları arası. Hacettepe Üniversitesi Eğitim Fakültesi Dergisi, 9(3), 614-626.

Yücedağ, T. ve Erdoğan, A. (2011). 2000-2009 Yllları arasında matematik eğitimi alanında Türkiye'de yapılan çalışmaların bazı değişkenlere göre incelenmesi. Gaziantep Üniversitesi Sosyal Bilimler Dergisi, 10(2), 825-838.

Yıldırım, A., ve Şimşek, H. (2013). Sosyal bilimlerde nitel araştırma yöntemleri. (9. Bask1). Ankara: Seçkin.

Yılmaz, K., Dedeoğlu-Orhun, B., Kılıç-Şahin, H. ve Bahar, H. Ö. (2010). Türkiye'de eğitim denetimi alanında bilimsel bilgi üretimi: Eğitim dergileri ve bilimsel toplantllar örneği. II. Uluslararası Katılımlı Eğitim Denetimi Kongresi içinde (s.300-310). Kütahya: DPÜ Eğitim Fakültesi \& TEMSEN.

Zhang, Y., ve Wildemuth, B. M. (2009). Qualitative analysis of content. İçinde B. M. Wildemuth (Ed). Applications of social research methods to questions in information and library science içinde (s. 308-319). California: Libraries Unlimited.

\section{Kaynakça Bilgisi / Citation Information}

Yıldız Altan, R., Genç Çopur, H. ve Dağlığlu, E. H. (2021). Türkiye'de okul öncesi dönemde matematik alanında yapılan çalışmalara ilişkin bir içerik analizi. OPUS-Uluslararası Toplum Araştırmaları Dergisi, 17(33), 619-653. DOI: 10.26466/opus.778998 